\title{
Autonomia and the political: an Italian cycle of contention, 1972-79*
}

Phil Edwards

\section{Introduction}

Two episodes of crowd trouble, as reported by the Italian Communist Party's daily paper l'Unità.

the demonstrators showed their determination to avoid a confrontation [...] suddenly police violence broke out [...] Police charges continued; to defend themselves the young people blocked via della Panetteria and via dei Crociferi with cars. Some cars were burned out. [...] The students made repeated attempts to leave the University, which was completely surrounded; every time, they had to face police violence. In the evening, to protect themselves from charges by police jeeps, the students blocked all the roads around the University with improvised barriers; police charges continued throughout the area ${ }^{\mathrm{i}}$

(Marzullo 1969) ${ }^{\mathrm{ii}}$

the stewards' groups fiercely blocked the way, attempting to prevent contact between the police (who certainly weren't looking for it) and groups of 'autonomist' provocateurs (who seemed to be there for nothing else) [...] there was the sense of an organised manoeuvre, in the true sense of the word, and police intervention became inevitable: stones were thrown from one side, tear-gas grenades from the other. [...] The police avoided a confrontation for as long as possible, enabling the stewards to prevent yet another excursion by these 'autonomists' [...] a 'commando' group broke away from the group of 'autonomists' and ran towards the supermarket. Once again, police intervention was inevitable $\mathrm{e}^{\mathrm{ii}}$ (Anon. 1976)

The differences between the two pieces are striking. In 1969, 1'Unità condoned students burning cars as a defence against unprovoked police violence; in 1976, police use of tear-gas grenades was presented as a reluctant but 'inevitable' response to stone-throwing by provocateurs.

I shall argue that each of these scenes shows a cycle of contention approaching its peak, and that the differences in the way the two cycles are presented reflects the different roles played by the Partito Comunista Italiano (PCI; Italian Communist Party). The first cycle, running from 1966 to 1972, is described by Sidney Tarrow's Democracy and disorder (Tarrow 1989). In this cycle the PCI took the role of gatekeeper, occupying the borderline of political legitimacy and overseeing the absorption of the movement's innovations by mainstream political forces. The process expanded the repertoire of the PCI, and hence that of legitimate institutional politics. At the same time, the PCI's assertion of ownership over the movement's innovations meant that the space available within the movement sphere contracted; the movement's diehard loyalists were condemned to irrelevance, marginality and criminality.

Tarrow presents the period from 1973 to 1980 as a long-drawn-out aftermath of this first cycle, in which movement organisers competed for the loyalties of a dwindling pool of activists by adopting progressively more 'extreme' and violent tactics. I shall argue, by contrast, that a second cycle of contention can be traced, running approximately from 1972 to 1978. The PCI, again in the role of gatekeeper, barred the entire movement from the mainstream: not only the movement's loyalists but its entire body of innovations were dismissed as irrational, deviant and criminal. The result was a contraction of the PCI's own repertoire, driven by the need for 
dissociation from the new movement; the movement itself, meanwhile, was subject to the full weight of police repression, with the result that little remained by 1979 except disorganised, small-scale violence. Tarrow presents the groups of the mid-1970s in terms of isolation, clandestinity and voluntaristic commitment to terrorist methods; I shall argue that these conditions only prevailed at the end of the decade, following the PCI's exclusion of a new wave of movements from the mainstream and their subsequent repression.

\section{Social movements and cycles of contention}

Social movements can be defined as groups within society which combine three factors: an oppositional or reformist stance towards the political status quo; autonomy from the conventional political sphere; and a degree of ideological or cultural coherence. Geographical extension and persistence over time are not essential to the definition: there have been recognisable social movements based in a single city (e.g. the Palermo-based anti-Mafia movement of 1990-3) or limited to a single year (e.g. the 'movement of 1977').

Tarrow has proposed a model of the social movement lifecycle based on Charles Tilly's concept of the 'repertoire'. The 'repertoire' situates forms of action within their social and historical context: a group's actions are related not only to its goals and resources but to the social context within which it operates. "The repertoire is at once a structural and a cultural concept, involving not only what people do when they are engaged in conflict with others but what they know how to do and what others expect them to do." (Tarrow 1998: 30; emphasis in original) Tarrow's concept of the protest cycle or 'cycle of contention' (Tarrow 1998: 142) relates the evolution of social movements to innovation in repertoires of action. Social movements emerge by developing new forms of action, which ultimately become available to society as a whole:

Cycles of contention are the crucibles within which new cultural constructs born among critical communities are created, tested and refined. These enter the culture in more diffuse and less militant form, where they can serve as sources for the symbols of future movements. (Tarrow 1998: 145)

Repertoire innovation promotes the assertion of new collective identities and the development of new mobilising structures - in short, the formation of a social movement. This in turn gains mass support as its new repertoire is seen to produce favourable results. Social movement success promotes the emergence of new movements around the same or similar repertoires; it can also prompt the assimilation of the new movement by the institutions of the conventional political sphere, effectively neutralising the new repertoire. The protest cycle peaks with widespread diffusion and emulation, then declines as assimilation and neutralisation gradually prevail.

Tarrow also argues that, as existing organisations adopt the new repertoire 'in more diffuse and less militant form', social movements respond by offering ever more radical repertoires and frames. In the Italian example the 1960s saw innovation, the 1970s only 'outbidding':

we can only link the terrorism of the late 1970s back to the mass movements a decade earlier by tracing a two-step process of competition, outbidding and separation within the social-movement sector. In the first stage, the extraparliamentary left competed for support with the PCI and the trade unions by proposing radical — but mass - forms of collective action to the workers. In the second, a new generation of autonomous groups, collectives and terrorist organisations competed for support with the extraparliamentary groups by proposing more 
radical, sectarian forms of collective action which — in the absence of a mass base - had to be violent to gain attention. (Tarrow 1991: 60)

The outcome is the demobilisation of the new movements - following a period of increasingly violent and isolated activity by diehard activists - and the absorption and legitimation of most of the new repertoire; this results in "a permanent expansion of the repertoire of democratic participation to include forms of action that were not present before" (Tarrow 1989: 67).

This model assumes a high degree of systemic closure, together with an inclusive approach by political actors. There is no consideration of situations in which a new movement enters the political system in its own right, or in which a new repertoire is rejected outright. Nor does Tarrow register the conflictual quality of the interaction between movement and gatekeeper: the appropriation of some elements of the repertoire will come at the cost of the rejection of others, which are framed as deviant, delinquent or criminal and hence left liable to repression. Tilly shows this process taking place in the definition of the strike:

It is not simply that legislators made some forms of the strike legal and other forms of the strike illegal. That happened, too. But in the process the antagonists created-in practice as well as in theory - a sharper distinction between the strike and other forms of action with which it had previously often been associated: sabotage, slowdown, absenteeism, the demonstration. A narrowed, contained strike entered the repertoire of workers' collective action.

(Tilly 1979: 134-5; emphasis in original)

An inclusive approach will result in a minority of the movement's innovations being framed as deviant or criminal. If, on the other hand, an exclusive approach prevails, the entirety of the movement's repertoires may be rejected; the result will not be "a permanent expansion of the repertoire of democratic participation" (Tarrow 1989: 67) but its contraction, as the gatekeeper prunes its own repertoire to eliminate any overlap with that of the movement.

\section{The first cycle, 1966-72}

The unrest of the cycle of 1966-72 began with a series of university occupations. Tactical and ideological innovation made the movement an explosive success. The key tactical innovations were the occupation and the assembly, both of which served political as well as organisational purposes. An assembly, in particular, was not a simple mass meeting, but a decision-making body open on an equal basis to all participants in an action. "Lively and confrontationist, the new movement was notable not only for its size, but also for its efforts to redefine the very notion of politics, constructing forms of organisation - above all, the permanent 'assembly' which simply and brutally swept the traditional student bodies aside." (Wright 2002: 89)

During 1968, the diffusion of the movement saw its focus shift to industrial activism, under the influence of the operaista ('workerist') strand of Marxism. At many factories, a Comitato Unitato di Base (CUB; 'United Rank and File Committee') developed, operating outside union structures and holding meetings open to local student activists. A new repertoire of industrial action developed, including strike forms such as 'hiccuping' strikes which were called off within minutes, then restarted, and 'chessboard' strikes which alternated between different areas of a factory. Several groups grew out of the movement, notably the Leninist and factory-oriented Potere Operaio ('Worker's Power') and the more spontaneist Lotta Continua ('Continuing Struggle'); both had roots in the workerist milieu. 
From 1969 onwards the institutional left began an engagement with the new movement, with a resurgence in activity by the Communist-affiliated Confederazione Generale Italiana dei Lavoratori (CGIL; General Italian Workers' Confederation). Wage levels across Italian industry were set through three-year contracts between unions and public- and private-sector employers' organisations. In 1969 the contracts were due for renewal; CGIL organisers attempted, with some success, to integrate innovative forms of industrial action into contractbased campaigns. As well as a favourable contract, December 1969 saw the passage of the Statuto dei Lavoratori ('Workers' Statute'), entitling workers to hold union meetings in work time; this became law the following May, together with a general amnesty for those who had been charged with offences relating to industrial action (Lumley 1990: 251). Innovative and disruptive workplace activism continued for some time and even spread, but it now took place with the effective approval of the unions - and, over time, was increasingly subordinated to the unions' perspectives and goals.

In the aftermath of the cycle, as industrial action declined, Lotta Continua launched a succession of initiatives aiming to organise in the underdeveloped south, in the armed forces and among prisoners. Their main effect was to mask the decline of the group with voluntaristic activism.In 1971 Potere Operaio established a sub-group dedicated to 'illegal work', tasked with preparing for insurrectionary warfare and providing 'armed support' to demonstrations. Lotta Continua underwent its own 'militarist turn' in April 1972, endorsing both mass and vanguard violence, although this policy was abandoned with equal abruptness six months later. Potere Operaio disintegrated in 1973, under pressure from the nascent 'area of Autonomia'; Lotta Continua survived until 1976 but then dissolved, torn between the confrontational militancy of its servizi d'ordine and the growing institutional focus of its leadership (Malaspina 1996).

\section{Problems with Tarrow}

Tactical, organisational and ideological innovation; social and geographical diffusion; a final choice between institutionalisation and armed extremism: the match with Tarrow's model appears exact. However, there are several problems with the model. Firstly, the 1971-3 period saw significant beginnings as well as endings. The Italian women's liberation movement emerged in 1971, bringing together radical feminist, socialist feminist and reformist tendencies. The same year, the magazines Re nudo and L'erba voglio appeared in Milan, addressing themselves to 'young proletarians'. In Rome, the area of Autonomia began to take shape in 1972 with the founding of the Comitati autonomi operai di via dei Volsci (CAO or ' $\mathrm{i}$ Volsci'; 'Autonomous workers' committees of via dei Volsci') (Monicelli 1978: 116).

Secondly, Tarrow's account of the spread of 'armed struggle' repertoires is sketchy. He writes: "once worker mobilisation declined, there was little real possibility of employing the energies of these young people in a serious project of industrial conflict [...] the extra-parliamentary groups left them with a rejection of reformism, with the tools of violence, but with little else." (Tarrow 1989: 308) The result was terrorism and clandestinity: "extraparliamentary groups used mass mobilisation to outbid the unions and the PCI, while the terrorists used violence to outbid the extraparliamentary groups." (Tarrow 1989: 310); "[t]he more radical [a group's] forms of action, the greater the risk of violence and the higher the level of repression. Once repression is triggered, the group has no alternative but to go underground, where the only tactical alternatives left to it are violent." (Tarrow 1991: 58) Tarrow elides the distinctions between types of 'radical' activity, while assuming that violence led inexorably to clandestinity, isolation and defeat. 
Thirdly, Tarrow's account of the 'area of Autonomia' is unpersuasive. He associates Autonomia with the trio of terrorism, clandestinity and isolation, presented in pathological terms:

in the mid-1970s [...] a collection of miscellaneous clandestine and semi-clandestine groups formed what came to be called the 'area of autonomy'. For these groups, autonomy meant separation from the state, from the institutional Left, from the unions, and eventually from reality.

(Tarrow 1989: 132)

[after 1974] the banner of autonomy, first raised by the students in 1966-8 to call for grassroots democracy, was used to wrap a faction of the extreme Left in clandestinity and mask its acts of terror in a rhetoric that-however hard they tried — could not cloak its members' detachment from the masses.

(Tarrow 1989: 133)

As a description of the area of Autonomia at its mid-1970s peak, this is highly misleading. The underlying problem is that Tarrow disallows the possibility of repertoire innovation where violence is used, referring violent activity to the category of 'outbidding'. This a priori dismissal of violent repertoires leads him to telescope the history of the area of Autonomia, reading its eventual defeat in terms of deviant tendencies immanent from its formation.

Nor, finally, does Tarrow's timescale appear to fit the record. Referring to the year 1973, Tarrow writes: "the beginning of organised terrorism coincided with the definitive decline of mass violence and with the period in which small-group violence peaked." (Tarrow 1989: 307) The beginning of organised (left-wing) terrorism in Italy can be dated to 1970, with the formation of the Brigate Rosse (BR; Red Brigades) and two other, more short-lived 'armed struggle' groups (Progetto Memoria 1994: 33, 41, 48). The diffusion of left-wing terrorism, however, came later. Table 1 shows the distribution, year by year, of the actions claimed by or attributed to the BR and other left-wing armed groups between 1970 and 1982.

Until 1976, non-BR armed activity is sporadic; thereafter it rises rapidly for two years, then declines more slowly over the next four. Over $75 \%$ of recorded actions took place in the three years from 1977 to 1979 . BR actions follow a similar trend, although the curve rises earlier and falls more slowly; the group's actions had a five-year peak, with over $68 \%$ of actions taking place between 1976 and 1980 . These effects may be related to the group's early establishment and its greater 'professionalism'. Both series suggest a milieu which grew suddenly between 1976 and 1979. If there was any spiral of outbidding, with rival claimants to the title of 'armed party' vying to adopt ever more violent tactics, it cannot have begun until 1976 at the earliest.

Table 2, on the other hand, suggests that 'the definitive decline of mass violence' cannot be dated as early as 1973 . The figures for workplace and university occupations suggest a resurgence in confrontational industrial activism, which goes into decline in 1976 and is succeeded by a wave of university occupations. Similarly, the figures for 'autoriduzione' actions - including housing occupations as well as autoriduzione and spese proletarie - trace a second cycle, beginning in 1974, peaking in 1976 and subsequently declining. In the category of demonstations, lastly, a level of activity below that of 1973 is not reached until 1979. The evidence suggests that armed struggle activity grew alongside the diffusion of 'mass violence'. If there was a transitional period, with terrorist groups flourishing as mass movements went into decline, it can be dated to 1978 at the earliest: in the aftermath of the second cycle rather than the first. 
In short, the history of Autonomia and its associated movements should be set against a second cycle of contention. In this perspective, the movement's defeat would follow, not from its 'detachment from the masses' or 'separation [...] from reality', but from the outcome of an 'engagement' phase comparable to the 1969-70 period. Even the questions of violence and legality are involved in this type of renegotation. In May 1970, the passage of the Workers' Statute and the accompanying amnesty meant not only that many of the innovations of the Hot Autumn ceased to be crimes but that many of its activists ceased to be criminals, even in retrospect. The contrast with the arrests of April 1979 and after, which criminalised Autonomia on the grounds of complicity with terrorism, is stark.

The second cycle of contention included at least three overlapping social movements: the area of Autonomia, the 'proletarian youth movement'/'movement of 1977' and the armed struggle milieu. A fourth, the women's liberation movement, can also be considered as part of the overall cycle, although its relations with the other three were complex and relatively distant. For the purposes of the present paper, I shall focus on the first two of these.

\section{Innovation: 1972-3}

In March 1973 the first national conference of 'Organismi autonomi' took place in Bologna. In addition to the Roman committees, delegates represented autonomous factory assemblies from the industrial centres of Milan and Turin as well as autonomous collectives from Bologna, Florence and Naples (Piazza 1987: 202). The conference's final resolution proposed the continual development of anti-capitalist activity, without respect for legality (Piazza 1987: 201). As Potere Operaio disintegrated, numerous groups entered the 'area of Autonomia', reorganising as more or less open 'committees' or 'collectives'.

The watchword of 'autonomy' evoked the workerist belief in the direct assertion of proletarian power through il rifiuto del lavoro ('the refusal of work') — the refusal, in other words, to accept the exchange of working time for a wage. This was seen not as a form of opposition to the employers within the capitalist system but as a declaration of 'extraneousness' from that system: 'the working class affirms its 'autonomy from capital', inasmuch as it not only refuses wage labour but fights against it, and in fighting reasserts its own otherness, difference and superiority relative to it' ${ }^{\text {iv }}$ (Piazza 1987: 175). In March 1973, workers at FIAT's Mirafiori factory in Turin went on strike in defiance of the 1972 contract settlement. An improved offer was produced on the $27 \mathrm{th}$; judging it inadequate, the workers occupied the factory on the 29th, exploiting the provisions of the Statuto dei Lavoratori to announce a 'permanent factory assembly'. The militancy of the occupation made a widespread impact, as did its apparent independence of all existing organisations. Both tactically and ideologically, Autonomia's repertoires were already more developed and more intransigent than those of the earlier movement.

\section{Diffusion: 1974-6}

After Mirafiori there was widespread wildcat industrial action. The new autonomous committees were supported by a new generation of workers, highly educated and politically unillusioned. As well as forms of strike action inherited from the earlier cycle, there was more open confrontation with managers and strikebreakers. However, this was more and more explicitly a defensive battle; managers at FIAT and elsewhere were restructuring entire production processes, farming out tasks to external plants and experimenting with automation. 
Moreover, the new movement, organised outside and against the unions, was forced to fight on two fronts.

Autonomia never had the same roots in the workplace as workerism's first wave. Its interventions outside the workplace, however, were widespread and creative, and found a receptive audience in working-class communities. Its first great success was autoriduzione ('self-reduction'). Beginning with workers at the Rivalta FIAT plant in Turin, who refused to honour an increase in bus fares, the tactic of 'self-reducing' prices spread throughout the Northern cities and Rome. Autoriduzione of electricity bills was particularly popular in Rome, where the $\mathrm{CAO}$ had a strong presence at the state-controlled electricity company, enabling members to reconnect households which had been disconnected for non-payment. 1974 also saw the first appearance of spese proletarie ('proletarian shopping'), when a group of demonstrators in Milan forced a supermarket manager to sell goods at reduced prices (Wright 2002: 159).

In September 1975 Autonomia appeared on the streets: demonstrations against Franco's Spain were followed by widespread rioting. As well as clashing with the police, the autonomists smashed shop windows and looted goods. On behalf of the PCI, former Partisan Antonello Trombadori pronounced anathema: "People who smash shop windows, like people who push for clashes with the police [...] must not find a place in the ranks of popular and proletarian mass action." (Monicelli 1978:56). Also in 1975, the 'creative' or 'desiring' wing of Autonomia emerged, rejecting political rationality and calling for the transformation of everyday life. The 'creative' area, centred on Bologna, was associated with intellectuals such as Franco 'Bifo' Berardi, the journal $\underline{\mathrm{A} / \text { traverso }}$ and the 'free radio' station Radio Alice.

The last and most significant episode in the process of diffusion was the rise of the 'proletarian youth movement'. In the autumn of 1975 groups of young people began meeting regularly in Milan. Their initial focus was the poverty of the options available to occupy their free time. The 'proletarian youth circles' began a threefold programme of activity: autoriduzione of the costs of leisure under the slogan of il diritto al lusso ('the right to luxury'); self-defence against threats to young people (neo-fascists, heroin pushers, sweatshop employers); and, least tangibly, stare insieme ('being together', 'hanging out'). The movement overlapped and finally merged with the movement for centri sociali ('social centres') (Moroni 1994). The centri sociali were empty buildings, occupied by autonomists and Lotta Continua militants as a base for local interventions. Their potential as a base for stare insieme made them particularly attractive to the 'circles'. Dozens of properties throughout Milan were taken over by the movement; ronde proletarie ('proletarian patrols') toured neighbouring streets, scouting for empty properties and attacking the enemies of the movement. Towards the end of 1976, the movement set up a central 'Coordinamento', complete with sub-committees (medical, legal, housing, anti-heroin, anti-sweatshop) and a journal, Viola (Moroni 1994: 58). In November a national Happening del Proletariato Giovanile ('Proletarian Youth Happening') was held in Milan.

The tactical repertoire of Autonomia expanded as it diffused, becoming increasingly complex, creative and reflective. With the development of the proletarian youth circles and centri sociali, autoriduzione tactics merged with the physical force tradition formed in the servizi d'ordine (stewards' groups) of the earlier wave, and with the new emphasis on stare insieme. The result was a coherent assertion of autonomy. The centri provided living quarters, company and a base from which the movement could impose itself on local shopkeepers and drug pushers alike. 
The growing self-confidence of the movement promoted a celebration of its 'extraneousness' and, on occasion, an outright refusal to communicate on terms which were not the movement's own. In particular, 1976 saw the spread of 'Indian' imagery and identities within the movement. The Indians' appearance — complete with feathers and war-paint—was a standing affront to 'straight' society; their exaltation of a semi-mythical native American culture flew in the face of industrial modernity. Above all, their use of language was playful, ironic and provocative, embodying a refusal to engage in dialogue with the mainstream-even the mainstream of Autonomia - except on their own terms. "The Indian heresy [...] aims simply to be the transgression of existing orthodoxies; to say No-even an unreasoning No- to logic and analysis, to 'thinkers', to anyone whose way of talking is difficult, boring or petty; and to say Yes to play, instinct, invention, unpredictability, collective creativity”vi (Monicelli 1978: 107)

\section{Engagement: 1977}

By February 1977, the movement and the PCI were on collision course. PCI leader Enrico Berlinguer had committed the party to opposing 'waste' in all its forms, including "laxity in work and study"vii (Berlinguer 1976); CGIL secretary Luciano Lama had stated that austerità ('austerity') was needed in order to combat inflation, specifically disavowing any industrial action centred on wage levels (Anon. 1977). The response in Rome was a wave of spese proletarie (Del Bello 1997: 5). When Rome University was occupied, the PCI declared its intention to "re-establish a space available for political activity" viii (Trombadori 1977).

The flashpoint came on February 17th, when Lama gave a speech at the occupied university. Speaking from the back of a lorry, surrounded by a CGIL servizio d'ordine, Lama was confronted by a vicious and absurd parody: a dummy on a cart, surrounded by 'Indians' and bearing a pink cardboard heart with the message "Nessuno Lama" ("Nobody loves him"). Lama exhorted his audience to save the university from destruction by the occupiers, just as the Resistance had saved the factories from the Germans (Lama 1977). Chanting ironic slogans such as "Più lavoro! Meno salario!" ("More work, less pay!"), the Indians pelted the servizio d'ordine with water- and paint-bombs. After Lama's address the servizio d'ordine went on the offensive. In response, the occupiers drove the Communists out of the campus, before withdrawing ahead of a massive intervention by the police (Rivolta 1977, Balestrini and Moroni 1997: 536-43).

La cacciata di Lama ('the expulsion of Lama') made a deep impression on both sides. The PCI could no longer deny either the size of the movement or its hostility. For the movement, years of criticism of the PCI now deepened to enmity. As a magazine from the 'creative' area reported, "The action carried out this morning by our comrade K. M., known publicly as Luciano Lama, succeeded beyond the most optimistic expectations." ${ }^{\text {"ix }}$ (quoted in Grispigni 1997: 48)

At the end of February, with the occupations movement flourishing across the country, a national meeting was held in Rome. The hard-line autonomists imposed themselves on the meeting; groups of metropolitan Indians and feminists, who walked out in protest, were prevented from re-entering by autonomist servizi d'ordine (Monicelli 1978: 142). With the movement under pressure in the form of political isolation, advocates of rival forms of 'autonomous' action and organisation grew more intransigent in pressing their claims; the participatory democracy of the 'assembly' form, inherited from the earlier cycle of contention, was unable to contain them. 
In Bologna on 11 March, carabinieri fired on demonstrators; one was shot dead. The movement responded with large-scale rioting, looting and arson. A commentator on Radio Alice recorded:

today's [...] was a demonstration which we all chose to make violent, without having stewards, without isolated pockets of provocateurs and autonomists carrying out actions, because all the comrades participated in all the actions which took place today ${ }^{\mathrm{x}}$ (quoted in Balestrini and Moroni 1997: 549)

The following day the police closed down Radio Alice and attempted to evacuate the occupied university; on 13 March carabinieri finished the job, descending on the university in armoured cars. The use of armoured cars against the movement - endorsed by a Communist-dominated local government-was traumatic. On 14 March, public meetings in Rome were banned until further notice. On 12 May an illegal but peaceful demonstration in Rome, called by the reformist Radical Party, was broken up by the police. A young Radical Party supporter was shot dead while she was running away. Two days later in Milan, a group of autonomists broke away from a march against government repression and opened fire on a group of police, killing a sergeant. A national meeting of the movement at the end of May narrowly agreed that, while violence was not acceptable unless guided by the movement as a whole, groups which carried it out remained part of the movement: "The movement does not carry out excommunications and does not accept the criminalisation of any of its elements"xi (quoted in Giachetta 1997). Repression intensified, with the full support of the PCI: 'special' (high security) prisons were established to house terrorists and other political criminals; the movement's so-called covi ('dens'), including the base in via dei Volsci, were searched and closed down; movement activists, numerous radical academics and publishers were arrested or questioned.

In September 1977, the movement held a conference against repression in Bologna, whose Communist mayor had pronounced it "the freest city in the world". Around 10,000 people attended the conference proper, which concluded - like the May meeting — by rejecting violence as a principle while refusing to dismiss it as a tactic (Monicelli 1978: 174). Deprived of organisational interlocutors, dismissed as freakish or criminal, the movement was now under intense pressure, internal as well as external. For one observer, Bologna exhibited

an unlimited potential for struggle, expressed in half a dozen more or less inspired slogans, but not so much as the shadow of a comprehensible political proposal. Only the sense that the movement was mortally tired of convoluted analyses and creative oddities - and thirsty for certainties, however fanatical ${ }^{\mathrm{xii}}$ (Monicelli 1978: 173-4)

\section{Aftermath: 1978-9}

The scale of the government counter-attack was making it impossible for the movement even to adopt political violence in collective — and potentially negotiable — terms. The initiative now passed to the advocates of armed action.

Several 'armed struggle' groups formed out of the area of Autonomia: examples include Proletari Armati per il Comunismo (PAC; 'Armed Proletarians for Communism') in Milan, whose victims included prison officials and shopkeepers who had killed burglars. A rapid recourse to high levels of violence was typical of groups formed at this stage: PAC's first murder was carried out in June 1978, a month after its first wounding (Progetto Memoria 1994: 138-9, 237-8) This period also saw the spread of terrorismo spicciolo ('small-change terrorism'): during 1978, in particular, numerous acts of sabotage or personal violence went 
unclaimed, or were claimed by labels such as Nuclei armati territoriali ('Armed territorial nuclei') or Ronde proletarie ('Proletarian patrols'). However, unlike the more 'professional' BR, these groups were heavily dependent on informal support — cultural, political and practicalfrom a broader movement. Already declining as the movement ebbed (Moss 1989: 77), this phase was rapidly brought to a close by intensified anti-terrorist policing-notably the arrests of mid-1979, which effectively criminalised what remained of the movement.

\section{The second cycle and the role of the PCI}

According to the model presented above, the engagement phase of a cycle of contention is the point at which a social movement comes into competition with institutional political forces, progressively reducing the options open to it within the movement sphere. In the inclusive version of the cycle, this process is compensated by the expansion of the institutional sphere; the movement's innovations are adopted while the movement itself is marginalised. We can follow this process in the first cycle of contention described above. In the second cycle, however, the process of engagement is exclusive, with the institutional gatekeeper adopting an unremittingly hostile position. The effect, consequently, is to contract the space available to the contending movements, consigning the movements as a whole to marginality and criminality.

This process is evinced by the lack of any serious attempt by the institutional left to open a dialogue with the movement. Rossana Rossanda, a prominent member of the left-wing Manifesto group, rejected Autonomia as an enemy ("We need to free ourselves of Autonomia Operaia, not only of its latest violent actions" ${ }^{\text {xiii }}$ ) and dismissed the broader movement as an outbreak of juvenile disaffection ("I understand what has led many young people to smash shop windows, but I don't consider it a stage in the Italian revolution." ${ }^{\text {xiv }}$ (quoted in Monicelli 1978: 150, 168)). Many Communists were more hostile. Lama was convinced that his February antagonists were fascists, citing their violence, their irrational slogans and their hostility to the PCI (Tornabuoni 1977); the PCI's Giancarlo Pajetta greeted the movement's conference against repression by warning that Fascism had also begun in Bologna (Moncalvo 1977).

Movement innovations were also suppressed outright, as in the widespread police action against movement members, publications and covi. The movement's larger organisational forms - the assembly, the march, the rally - were driven out of the universities and off the streets and squares; any overt use of tactical force, in a ronda or a 'proletarian shopping' trip, could and increasingly would be met with superior force.

\section{No alternative?}

It could be argued that the rejection of the movement was inevitable. The movement's tactical repertoire, in particular - the driving force of the cycle - was largely illegal (autoriduzione, spese proletarie, occupations) and often involved violence (ronde proletarie, rioting).

Moreover, the movement overlapped with the armed struggle milieu, which put a positive premium on acts of violence. Arguably the PCI could only refuse contact with a movement such as this.

However, an 'inclusive' engagement does not imply a friendly approach; the PCI had consistently treated groups such as Lotta Continua and Potere Operaio with hostility, even as it reappropriated their repertoires. In the case of the second movement, reappropriation was never attempted, but this does not mean that it was impossible. On at least one occasion Bologna's Communist council allowed municipal buses to be used free of charge in peak hours (Anon. 1973); in 1975 many CGIL branches gave a qualified endorsement to autoriduzione of 
electricity bills, albeit with a suggested reduction of $50 \%$ rather than the $75 \%$ proposed by the CAO (Wright 2002: 158). Nor should we suppose that, in celebrating 'extraneousness', the movement sought ghettoisation. Movement groups repeatedly attempted to open a political dialogue: in 1976 the Milan 'circles' presented a 'shopping list' of demands to be met by local and central government, including the requisition of empty buildings and the legalisation of soft drugs (Balestrini and Moroni 1997: 518-9). However, the increasing sophistication of the movement's demands was met by an abrupt retreat; when the movement most needed an interlocutor, the PCI was most intransigent in its defence of the status quo.

If the hostility of the PCI was not preordained, its effects were none the less inexorable. By mid-1979 there were few areas in which the autonomy, intransigence and creativity of the cycle could find expression other than 'small-change terrorism'. Tarrow writes of Autonomia: "These groups were practically born in clandestinity. With the decline of mass mobilisation of the early- and mid-1970s, the only way for them to gain the attention of the workers was through violence." (Tarrow 1991: 60) In fact groups answering this description did exist, but only after the repression of Autonomia itself. In the words of the narrator of Balestrini's 1987 novel, himself in prison awaiting trial for association with terrorists:

many of these new arrivals had ridiculous stories they were the last generation of fighters all extremely young and they all had a similar story they hadn't had any movement experience not least because by now the movement had been swept away their only experience was reading some document the clandestine distribution of some leaflet writing on the walls a banner across a flyover and then perhaps a murder straight away among the first actions and then arrest on the word of some informant (Balestrini 1987: 270) ${ }^{\mathrm{xv}}$

All the themes of the second cycle of contention could be seen here in degenerated form: direct action, disregard for legality, spontaneity, creativity, intransigence and autonomy. Their degeneration followed the movements' long and hostile engagement with the institutional left. 


\section{References}

\section{Books and papers}

Balestrini, N. (1987), Gli invisibili, Milan: Bompiani

Balestrini, N. and P. Moroni (1997), L'orda d'oro (revised edition), Milan: Feltrinelli

Del Bello, C. (a cura di) (1997), Una sparatoria tranquilla: per una storia orale del ' 77 , Rome: Odradek

Giachetta, D. (1997), "Il movimento del '77 e la violenza", Per il Sessantotto 11-12

Grispigni, M. (1997), "Elogio degli invisibili", in Virno et al. (1997), Millenovecentosettantasette, Rome: Manifestolibri

Lumley, R. (1990), States of emergency, London: Verso

Monicelli, M. (1978), L'ultrasinistra in Italia 1968-1978, Rome: Laterza

Moroni, P. (1994), "Origine dei centri sociali autogestiti a Milano", in Adinolfi et al, Comunitá virtuali. I centri sociali in Italia, Rome: Manifestolibri

Moss, D. (1989), The politics of left-wing violence in Italy, 1969-85, London: Macmillan

Piazza, G. (1987), "Movimenti e sistema politico: il caso di Autonomia operaia" (unpublished thesis), Università degli studi di Catania

Progetto Memoria (1994), La mappa perduta, Milan: Sensibili alle foglie

Tarrow, S. (1989), Democracy and disorder, Oxford: OUP

--- (1991), "Violence and institutionalisation after the Italian protest cycle", in Catanzaro (1991)

--- (1998), Power in movement, second edition, Cambridge: CUP

Tilly, C. (1979), "Repertoires of contention in America and Britain, 1750-1830", in Zald and McCarthy (eds.) (1979), The dynamics of social movements, Cambridge, MA: Winthrop

Vinciguerra, V. and M. Cipriani (1999), Oppressione, Repressione, Rivolte: Storia d'Italia dal 25 luglio 1943 ad oggi, online at $<\mathrm{http}: / / \mathrm{www}$.fondazionecipriani.it/Kronologia/introduzione.htm>

Wright, S. (2002), Storming Heaven: Class composition and struggle in Italian Autonomist Marxism, London: Pluto

\section{Newspapers}

Anon. (1973), “Trasporti pubblici gratuiti da lunedì a Bologna”, l’Unità, 29 March

--- (1976), “Manovre provocatorie preordinate da gruppi di teppisti”, l’Unità (Milan edition), 29 June

--- (1977), “Duemila lavoratori comunisti discutono le scelte anti-crisi”, l’Unità, 30 January

Berlinguer, E. (1976), "Il rapporto di Enrico Berlinguer al Comitato centrale e alla Commissione centrale di controllo", 1'Unità, 19 October

Lama, L. (1977), "Il discorso di Luciano Lama", l’Unità, 19 February

Malaspina, T. (1996), "LC: sette anni di guai", l'Espresso, 5 September

Marzullo, K. (1969), "Roma in stato d'assedio", l’Unità, 28 February

Moncalvo, G. (1977), “"Anche il fascismo cominciò con la marcia su Bologna”, Corriere della Sera, 20 September

Rivolta, C. (1977), “'I Lama nel Tibet', il leader in fuga”, La Repubblica, 19 February

Tornabuoni, L. (1977), "Si sposta sul piano politico la polemica per la guerriglia contro Lama all'università", Corriere della Sera, 19 February

Trombadori, D. (1977), “All'Università di roma ieri giornata di assemblee studentesche", l’Unità, 8 February 


\section{Endnotes}

*An earlier version of this paper was given at the ECPR Joint Sessions of Workshops in Edinburgh, 28th March to 2nd April 2003. I would like to thank Jim Newell, Martin Bull, Yannis Karamihas, Yota Papageorgiou, Gianni Piazza, Rudy Lewanski and Marlen Logotheti.

i "i dimostranti hanno dimostrato la loro determinazione di evitare lo scontro [...] improvvisamente, si è scatenata la violenza poliziesca [...] le cariche continuavano: per difendersi i giovani avevano sbarrato con auto via della Panetteria e via dei Crociferi. Alcune auto sono rimaste incendiate [...]

Ripetutamente, infatti, gli studenti hanno effettuato delle sortite dall'Università accerchiata ed ogni volta hanno dovuto affrontare la violenza poliziesca. In serata, per proteggersi dalle cariche delle jeep, gli studenti avevano sbarrato con ostacoli di fortuna tutte le strade adiacenti all'università: le cariche, infatti, si svolgevano in tutta la zona"

${ }^{\text {ii }}$ Where Italian material is quoted at length, a translation is given in the text with the original in an endnote. Single Italian words and brief phrases are given in italics, with a translation on their first appearance. Titles of organisations are not italicised, to avoid confusion with eponymous publications. iii "agguerriti schieramenti del servizio d'ordine nel tentativo di impedire il contatto tra le forze di polizia (che certo non lo cercavano) ed i gruppi di provocatori degli "autonomisti" (che sembravano essere lì appunto per questo) [...] si è avuta [...] la sensazione di una vera e propria manovra preordinata e l'intervento della polizia è stato inevitabile: lancio di sassi da una parte e di candelotti lacrimogeni dall'altra. [...] La polizia ha evitato fino in fondo lo scontro ed ha atteso che fosse lo stesso servizio d'ordine a bloccare l'ennesima sortita di questi 'autonomi; [...] un 'commando' si e staccato dal gruppo degli 'autonomi' e si è diretto a passo di corsa verso il supermercato. Ancora una volta l'intervento della polizia è stato inevitabile."

iv "la classe operaia afferma la sua 'autonomia del capitale' in quanto non solo rifiuta il lavoro salariato, ma lo combatte, e combattendolo riafferma la propria alterità, diversità e superiorità rispetto ad esso"

v "Chi spacca le vetrine del negozi come chi incita allo scontro con la polizia [...] non deve trovare spazio nelle file dell'azione di massa proletaria e popolare."

vi “L'eresia indiana [...] vuole semplicemente essere la trasgressione delle ortodossie esistenti; dire di no - anche un no immotivato - alla logica, alle analisi, ai 'pensatori', a chi parla in modo difficile, noioso, angusto; e dire di sì al gioco, all'istinto, all'invenzione, all'imprevedibilità, alla creatività collettiva."

vii "lassismo nel lavoro e nello studio"

viii "Obiettivo: ripristinare nell'Ateneo uno spazio di 'agibilità politica'."

ix "L'azione compiuta questa mattina dal nostro compagno K.M., conosciuto pubblicamente come Luciano Lama, ha sortito un effetto superiore alle più rosee previsioni." 
x "quella di oggi [...] era una manifestazione che tutti avevamo scelto di fare violenta, senza avere un servizio d'ordine, senza gruppetti isolati di provocatori, di autonomi, che facevano delle azioni, perché tutti i compagni hanno partecipato a tutte le azioni che si sono svolte oggi”

xi “Il movimento non fa scomuniche e non accetta la criminalizzazione di nessuna sua componente" xii "Un potenziale di lotta smisurato, che si scarica in una mezza dozzina di slogan più o meno ispirati; ma neanche l'ombra di una proposta politica decifrabile. Solo la sensazione che il movimento sia mortalmente stanco di analisi contorte e di bizzarrerie creative; e assetato invece di certezze, sia pure fanatiche."

xiii "Di Autonomia operaia e non solo delle sue violenze ultime occorre liberarsi."

xiv "Capisco quello che spinse molti giovani a spaccare le vetrine, ma non lo considero una tappa della rivoluzione italiana."

xv "molti di questi nuovi venuti avevano storie assurde erano l'ultima generazione di combattenti tutti giovanissimi e avevano tutti una biografia simile non avevano avuto nessun percorso di movimento anche perché ormai il movimento era stato spazzato via per cui il percorso era stato la lettura di qualche documento la distribuzione clandestina di qualche volantino scritte sul muri uno striscione su un cavalcavia e poi magari un omicidio subito tra le prime azioni e poi l'arresto su dichiarazioni di qualche pentito" 